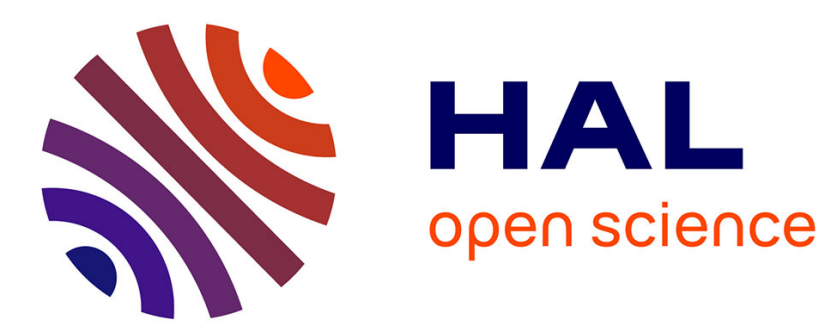

\title{
Provenance analysis by single-quartz-grain SEM-CL/optical microscopy.
}

\author{
Matthias Bernet, Kari Basset
}

\section{To cite this version:}

Matthias Bernet, Kari Basset. Provenance analysis by single-quartz-grain SEM-CL/optical microscopy.. Journal of Sedimentary Research, 2005, 75, pp.496-504. hal-00097132

\section{HAL Id: hal-00097132 \\ https://hal.science/hal-00097132}

Submitted on 21 Sep 2006

HAL is a multi-disciplinary open access archive for the deposit and dissemination of scientific research documents, whether they are published or not. The documents may come from teaching and research institutions in France or abroad, or from public or private research centers.
L'archive ouverte pluridisciplinaire HAL, est destinée au dépôt et à la diffusion de documents scientifiques de niveau recherche, publiés ou non, émanant des établissements d'enseignement et de recherche français ou étrangers, des laboratoires publics ou privés. 
Running head: SEM-CL/optical microscopy of quartz

\title{
PROVENANCE ANALYSIS BY SINGLE-QUARTZ-GRAIN SEM-CL / OPTICAL MICROSCOPY
}

\author{
MATTHIAS BERNET ${ }^{1}$ and KARI BASSETT \\ Department of Geological Sciences, University of Canterbury, Private Bag 4800, \\ Christchurch, New Zealand \\ ${ }^{1}$ Corresponding author, present address: LGCA, Université Joseph Fourier, 38041 Grenoble \\ Cedex 9, France, email: matthias.bernet@aya.yale.edu
}

Keywords: quartz arenite, SEM-CL, optical microscopy, provenance, New Zealand

ABSTRACT: The integration of panchromatic scanning electron microscopycathodoluminescence (SEM-CL) with optical microscopy analysis on single quartz grains is a new technique to interpret provenance of quartz-rich sediments. The combination of information gained from SEM-CL on textural features and CL response with information from optical microscopy allows distinction of different quartz types much more easily then with conventional microscopy or color $\mathrm{CL}$ analysis. Features visible by SEM-CL include zoning, microcracks, deformation fractures and lamellae, diagenetic crushing, recrystallization, and strength and texture of CL response. Features visible by optical microscopy include embayments, open fractures, extinction behavior and mono-, poly-, and microcrystallinity. The key is to integrate CL and optical properties of the same quartz grains in order to reduce 
ambiguities inherent in both techniques used on their own. Our technique is well suited for distinguishing between plutonic, volcanic, and metamorphic quartz in coarse- to mediumgrained sand or sandstone. This simple and inexpensive approach can easily be combined with other provenance techniques. In this paper we outline the combined SEM-CL/optical microscopy technique and demonstrate its application with examples from the South Island of New Zealand.

\section{INTRODUCTION}

A variety of different petrologic, isotopic, and geochemical provenance techniques have been developed over the years to study the provenance of detrital quartz. One recent development is using the panchromatic scanning electron microscope - cathodoluminescence (SEM-CL) technique for quartz provenance analysis (e.g., Milliken 1994; Seyedolali et al. 1997; Kwon and Boggs 2002). In particular, Seyedolali et al. (1997) identified a series of CL characteristics and features that help to determine quartz provenance. However, Kwon and Boggs (2002) demonstrated that SEM-CL by itself supplies different provenance answers than conventional point counting does for the same samples. Therefore, these authors concluded that SEM-CL must be combined with optical petrographic analysis in order to determine sediment provenance correctly.

We have built on the research of Seyedolali et al. (1997) and Kwon and Boggs (2002) to develop a new provenance analysis technique using integrated SEM-CL and optical analysis on the same individual quartz grains. The purpose is to be able to distinguish between plutonic, volcanic, and metamorphic quartz in coarse- to medium-grained sand or sandstone using a rigorous technique that is independent of petrographer bias and is repeatable. Our approach is to distinguish between primary CL characteristics developed in quartz during crystallization and cooling, and secondary textural features or fabrics acquired subsequently (Table 1, Fig. 1). These CL characteristics and fabrics are then combined with important optical information such as extinction behavior of each quartz grain.

In this paper, we first present the technique of integrating SEM-CL and optical petrographic analysis of fabrics and textural features within quartz grains before we demonstrate the application of 
this new technique with examples of volcaniclastic sand from Lake Taupo, New Zealand, and quartz arenite from the Eocene Broken River Formation, New Zealand.

\section{ANALYTICAL METHODS}

Integrated SEM-CL/optical microscopy analysis on single quartz grains is a fairly simple and inexpensive technique. All that is needed are highly polished thin sections of sand or sandstone samples, a personal computer for image enhancement and analysis, a standard optical microscope, and an SEM or electron microprobe with a panchromatic CL detector, which is a relatively inexpensive attachment. We used a Leica Stereoscan 440 SEM and a Gatan MiniCL cathodoluminescence detector for SEM-CL analysis. The MiniCL detects luminescence in the 185-850 nm wavelength range, but it has no optical filters and does not allow quantitative treatment such as analysis of intensity versus wavelength. Digital panchromatic images were taken at $1.0 \mathrm{nA}$ beam current and $15.0 \mathrm{kV}$ acceleration voltage at an average working distance of $22 \mathrm{~mm}$. Mineral identification was supported by chemical spot analyses using an Oxford Link ISIS X-ray EDS analysis system. Images were taken at 4096 pixel average, which corresponds to a scan time of about 5 minutes. In general, images were enhanced

afterwards with a commercial photo editing program. For optical microscopy we used a Leitz polarizing microscope with $2.5 x$, 5x, and $10 x$ objectives.

\section{SEM-CL AND OPTICAL CHARACTERISTICS OF QUARTZ TYPES}

Building on Seyedolali et al. (1997), we first established a reference data base (available upon request) of quartz types using combined SEM-CL and optical petrography on the same crystals to characterize the reference types. Over one thousand single quartz grains from over 80 different samples of different plutonic, volcanic, and metamorphic rocks were analyzed in this study using the integrated CL/petrography method.

Quartz is a relatively low-luminescence mineral in comparison to many feldspar and carbonate minerals, and the cause of luminescence in quartz is not yet fully understood. Luminescence may result from $\mathrm{Al}$ substitution for $\mathrm{Si}$, intracrystalline variation in trace- 
element concentrations, or linear or point defects in the quartz crystal structure (Perny et al. 1992; Watt et al. 1997; Ramseyer and Mullis 2000; Stevens-Kalceff et al. 2000). A variation in CL color with respect to quartz $c$-axis orientation has been described by Walderhaug and Rykkje (2000) but was not observed in our study using panchromatic SEM-CL.

Quartz crystals can contain a variety of textural features such as defects in the crystal structure (e.g., microcracks, healed cracks, microfractures deformation lamellae etc.) or zoning, which may be visibly enhanced because of variation in luminescence within the crystals (Table 1). However, quartz crystals low in defects or intracrystalline chemical variation (trace elements etc.) can appear homogeneous in light gray to black with no variation in CL intensity (e.g. Boggs et al. 2002). Note that light gray, dark gray or black are only relative terms used here just to describe CL appearance in panchromatic images. Black CL does not mean nonluminescence, but can actually be dark red in color CL images. High and low luminescent are as well descriptive terms used in a similar way, where high luminescence corresponds with bright white or light gray and low luminescence with dark gray or black CL in panchromatic SEM-CL images.

Information on extinction behavior, such as non-undulose, weak undulose (5-10), and strong undulose $\left(>10^{\circ}\right)$ extinction (e.g., Basu et al. 1975; Tortosa et al. 1991), and on the formation of subgrain boundaries, recrystallization, and mosaic quartz are obtained by optical microscopy (Young 1976; Passchier and Trouw 1996). Features and characteristics that can be observed with both techniques include grain shape (euhedral, rounded, embayments, etc.), and certain deformation features (e.g., open cracks and fractures, deformation lamellae).

\section{Plutonic Quartz}

Typical plutonic quartz is characterized by large crystals containing open and/or healed microcracks, fluid-inclusion trails, and non-undulose to slightly undulose extinction. Fluid inclusion trails and extinction can easily be seen with an optical microscope, but the microcracks are visible mainly with CL (Fig. 1A, B). 
Microcracks or healed cracks are not related to crystal cleavage but are formed because of thermal stress in the crystal during postmagmatic cooling (Moss and Green 1975; Sprunt and Nur 1979). Such cooling-related microcracks are randomly oriented (Fig. 1A). In fact, plutonic quartz crystals may have several generations of microcracks or healed cracks (Moss and Green 1975). All plutonic quartz crystals analyzed in this study showed microcracks and/or healed cracks, making these features highly diagnostic for plutonic quartz. We also observed zoning in some plutonic quartz, but generally it was rare in our samples. Nevertheless, D'Lemos et al. (1997) described this phenomenon in more detail from quartz of the southwest granite complex of Jersey, UK.

\section{Volcanic Quartz}

Volcanic quartz appears as pristine crystals in thin sections under an optical microscope, showing non-undulose extinction and commonly idiomorphic or hypidiomorphic crystal shape. SEM-CL analysis of our samples showed that half of the volcanic crystals have zoning while the other half have mainly homogeneous CL ( 30\%) or inhomogeneous, somewhat patchy CL ( 20\%). Volcanic quartz crystals may also contain melt inclusions, embayments, and large open cracks, which are visible with an optical microscope but can also be seen with SEM-CL (Fig. 1C, D).

Many zoned crystals show a complex growth history, with periods of crystal growth and periods of readsorption of crystal material into the melt, and subsequent mineral growth again (Fig. 1C). This tends to make the zoning in volcanic quartz appear more rounded and/or embayed than that found in vein quartz. Zoning in quartz crystals may reflect changes in the rate of crystal growth or chemical variation of the melt during crystallization (Watt et al. 1997).

\section{Metamorphic Quartz - Deformed to Recrystallized}

The distinction of quartz that was deformed, metamorphosed, and/or recrystallized under lowgrade, medium-grade, or high-grade metamorphic conditions is difficult because of the overlap of characteristics and features and subtle change in CL depending on protolith, deformation style, and metamorphic grade. Even though clear-cut categories are difficult, we attempt to differentiate quartz 
types according to their deformation and metamorphic history. Because of the large transitional range of features in low-grade to high-grade metamorphic quartz further detailed research is needed.

\section{Low-Grade Metamorphic Quartz with Brittle Deformation}

Brittle deformation of quartz grains occurs under nonmetamophic to very low-grade or low-grade metamorphic conditions $\left(<300-400^{\circ} \mathrm{C}\right)$ and is formed during burial, or local or regional tectonic deformation. Such brittle deformation causes microfractures with preferred orientations that correspond to the local or regional strain field during deformation (Kanaori 1986). Tectonically induced microfractures can also subsequently be healed, and they appear as parallel black to gray linear features in SEM-CL images (Fig. 1B). Besides the introduction of microfractures, the original CL characteristics and features of a quartz crystal do not change under such metamorphic conditions (Fig. 1A). It is important to note the difference in terminology here between microfractures (related to deformation) and microcracks (related to cooling of plutonic quartz).

\section{Medium-Grade Metamorphic Quartz with Ductile Deformation}

The onset of ductile deformation with increasing metamorphic grade $\left(400-700^{\circ} \mathrm{C}\right)$ is marked by the occurrence of deformation lamellae, deformation bands and medium to strong undulose extinction in quartz (Passchier and Trouw 1996). Deformation lamellae can be examined with both SEM-CL and optical petrographic techniques, while deformation bands, and undulose extinction are visible only with an optical microscope. Increasing deformation leads to stronger undulose extinction, and quartz crystals with strong undulose extinction tend to develop inhomogeneous, patchy or mottled CL. We observed such a change in CL response toward darker and more patchy or mottled CL in quartz of the nonmetamorphic to low-grade and medium-grade metamorphic Hohonu Batholith and the mediumgrade to high-grade metamorphic rocks of the Cape Foulwind area on the South Island of New Zealand (Fig. 2). Cape Foulwind is a metamorphosed plutonic complex that experienced different degrees of deformation and metamorphic overprint. We found that original plutonic quartz CL characteristics (relatively light CL, microcracks, and healed fractures) can be partially preserved in medium-grade metamorphic rocks, but these characteristics successively disappear with increasing 
metamorphic grade, being completely removed when quartz is fully recrystallized (see data archive for more information).

\section{High-Grade Metamorphic Quartz with Recrystallization}

Recrystallized quartz is readily recognized under the optical microscope and in some cases in SEM-CL by polygonization forming quartz mosaics. Approximately $95 \%$ of quartz grains recrystallized under medium-grade to high-grade metamorphic conditions appear very dark gray or black in panchromatic SEM-CL images in this study, and the disappearance of previously acquired textural features such as zoning, microcracks, or deformation lamellae is the rule. Such a change in features and CL intensity from light gray to dark gray or black in low-grade to high-grade metamorphic and recrystallized quartz is in accord with the findings of Sprunt et al. (1978), who described changes in quartz color CL with increasing degrees of metamorphism

Where quartz recrystallization is not complete, it is possible to recognize remnants of original grains with preexisting features surrounded by recrystallized domains (Fig. 1E). This phenomenon can be seen in partly recrystallized quartz of an orthogneiss at Cape Foulwind, in the South Island, New Zealand (Fig. 2; also see data archive). The partly preserved plutonic quartz can be recognized as areas of higher luminescence than the surrounding, fully recrystallized domains. Furthermore, the plutonic quartz remnants contain microcracks and healed fractures in SEM-CL images, and they show undulose extinction, while surrounding fully recrystallized quartz mosaics usually have non-undulose extinction under an optical microscope.

\section{Vein Quartz}

We include vein quartz in the metamorphic quartz group because quartz veins generally appear in metamorphosed rocks and the quartz shows characteristics very similar to those of recrystallized, highgrade metamorphic quartz. About $80 \%$ of the vein quartz examined in 10 samples for this study consisted of recrystallized quartz, all of which had a very dark and homogeneous CL response. However, nonrecrystallized vein quartz also occurs. We found that the greater part $(>75 \%)$ of 
nonrecrystallized vein quartz shows patchy or mottled CL and weak to strongly undulose extinction similar to what we classify as metamorphic quartz.

Vein quartz can combine a variety of characteristics found also in plutonic and volcanic quartz. Zoning in vein quartz seems to be a common feature and can be best observed with panchromatic SEM-CL (Onasch and Vennemann 1995; Rusk and Reed 2002) and color CL (Perny et al. 1992), but not with the petrographic microscope. Although it has been described extensively, it was found to occur in less than five percent of the vein quartz we examined in this study, making it not particularly diagnostic. In contrast to the rounded zoning in volcanic quartz, the observed zoning in vein quartz was oscillatory, concentric, and narrowly spaced with sharp corners (Fig. 1F). Healed cracks such as those typical of plutonic quartz have also been described in the literature but were found in less than $1 \%$ of all vein quartz examined in this study.

\section{Recycled Sedimentary Quartz}

Sediment recycling is always a concern in sediment provenance studies. In certain cases, combined SEM-CL and optical analysis has the potential to identify recycled quartz. Inherited authigenic overgrowth around detrital quartz, a feature which has long been recognized as an indicator for sediment recycling (e.g., Sanderson 1984), is easily seen by CL because authigenic quartz has black CL in contrast to lighter CL of most detrital quartz. In contrast, identification of recycled detrital quartz by optical petrography is dependent on the presence of dust rims.

CL can also be used to identify brittle deformation of quartz grains that occurs during diagenesis and compaction of sediment in any given sedimentary basin. Such deformation is characterized by shattering along grain contacts, and it can be recognized only with CL (Dickinson and Milliken 1995; Milliken and Laubach 2000). In fact, the same grains would look as though they had experienced brittle deformation (Milliken and Laubach 2000). Grain shattering is visible with CL because the grain fragments maintain their original CL intensity and features while authigenic quartz has dark CL (Houseknecht 1991; Hogg et al. 1992; Dickinson and Milliken 1995; Milliken and Laubach 2000). Therefore, combined SEM-CL/petrographic analysis helps to identify such recycled grains. 
Microcrystalline quartz varieties such as chalcedony and chert appear similar to recrystallized quartz and some vein quartz in SEM-CL images with a dark CL response. Therefore, these quartz varieties are best recognized and distinguished from other quartz types with the optical microscope.

\section{INTEGRATED SEM-CL / OPTICAL MICROSCOPY}

Because of the overlap of certain CL features in different quartz types, additional information is required to determine quartz provenance more reliably. Therefore, we propose an integrated approach that applies SEM-CL and optical analysis to the same quartz grains to remove ambiguities in identifying quartz types (Table 2). Furthermore, we want to produce specific quartz-type point counts which can be compared to conventional point counting of all clastic components.

The integrated approach is summarized here. First, uncovered and well polished thin sections are needed, and they must be inspected with an optical microscope to check for polishing quality because uneven surfaces cause unwanted artifacts and disturbances while acquiring SEM-CL images. Areas selected for analysis should be marked on the thin section with a felt-tip pen to ensure that the same areas can be found with the SEM and for the grain-by-grain comparison of SEM-CL and optical features later on. Carbon coating is necessary to allow discharge of electrons and avoid sample damage during electron bombardment, but the coating is very thin so optical microscopy is not compromised later. Care must be taken to produce thin, even coatings, because artifacts can be introduced by irregularities.

SEM-CL images should be taken at a variety of magnifications depending on grain size, sorting, and the presence of associated, perhaps more highly luminous minerals. Overview images (50x) should be supported by a series of close-up images at 100-150x magnification for samples of coarse to medium sand size or up to 200-300x magnification for samples of fine sand size.

At least 100 randomly selected quartz grains, either by use of a grid or all within a specified area, should be labeled on the overview images for point-counting purposes and for individual comparison with optical microscopy (Fig. 3). All other grains (feldspar, lithics, etc.) are ignored. Placing the 
optical microscope next to the computer with the labeled SEM-CL images allows direct comparison of individual quartz grains by each method. Thus information from optical microscopy can be directly integrated with information from SEM-CL analysis when identifying quartz types (Fig. 4). Shape and size of individual quartz grains should also be noted. All information from both techniques for each individual grain can be compiled in a spreadsheet enabling repeatable identification of quartz types, reduction of operator bias, calculation of frequency of occurrence of the different properties, and identification of stratigraphic trends.

We found that this provenance technique works best for coarse-grained to medium-grained sand and sandstone, but it is also applicable to fine sand sizes. However, the smaller the grains, the more difficult it becomes to distinguish between certain quartz types. For example, both volcanic quartz and vein quartz may show dark CL and non-undulose or weakly undulose extinction. In addition, quartz grains may break along fractures such as microcracks in plutonic quartz, leaving only small grains with ambiguous characteristics. Therefore, we recommend the use of this technique for sand-size sediment only and mainly for coarse to medium grain sizes.

Difficulties in this technique can arise during acquiring CL images. We experienced interference problems with high-luminescence inclusions such as apatite or zircon. Calcite cement can cause interference as well, which may lead to low-quality CL images. Close-up images can reduce this problem, as can the dissolution of the calcite cement prior to polishing.

\section{APPLICATION OF THE NEW PROVENANCE ANALYSIS TECHNIQUE}

Application of integrated SEM-CL/optical microscopy provenance analysis of quartz is demonstrated here on volcaniclastic sands from Lake Taupo and quartz arenites of the shallow marine, Eocene to Oligocene Broken River Formation at Mount Somers and Glens of Tekoa, New Zealand (Fig. 2). One hundred randomly selected quartz grains were analyzed with integrated SEM-CL/optical analysis in each sample and classified following Table 2. All samples were also point counted using traditional techniques. The results are summarized in Table 3.

We compared detrital quartz to our quartz SEM-CL reference database in order to identify quartz types. For the purpose of this study and for simplicity in data presentation we distinguish here between 
plutonic, volcanic, and metamorphic quartz (Fig. 5A). Metamorphic quartz includes all low-grade to high-grade metamorphic and recrystallized quartz as well as vein quartz. This simplification is justified because vein quartz is usually found in the metamorphosed basement rocks of the proposed source areas. The diagram shown in Figure 5A is therefore specifically designed for this study of New Zealand samples and may need to be modified for other settings, particularly where recycled sedimentary quartz is abundant.

We also analyzed quartz from local volcanic bedrock (dacite, rhyolite, and ignimbrite) in the Lake Taupo area as well as in the Mount Somers area. This allowed us to directly compare detrital quartz in our sediment samples to local source rocks.

\section{Lake Taupo}

Lake Taupo is located in the Taupo Volcanic Zone (TVZ) on the North Island of New Zealand in an intra-arc extensional basin (Fig. 2). Active volcanism in this region is associated with subduction of the Pacific Plate beneath the Indo-Australian Plate along the Hikurangi subduction zone. Local bedrock consists of rhyolite, dacite, andesite and ignimbrites (Smith and Landis 1995). The Taupo caldera was formed by a series of eruptions starting at $1.85 \mathrm{Ma}$, with major events at $300 \mathrm{ka}$ and $65 \mathrm{ka}$ (Cole et al. 1998). Lake Taupo is a fairly recent feature that formed from caldera collapse in the Taupo volcanic center.

Medium-sand-size modern lake sediments were sampled along the shore of Lake Taupo at the town of Taupo. The sediment consists of $\sim 48 \%$ volcanic fragments (rhyolite, dacite, andesite, pumice, glass etc.), $\sim 19 \%$ feldspar, $\sim 23 \%$ quartz, and $\sim 10 \%$ shell fragments (Table 3, Fig. 5). SEMCL/optical microscopy analysis showed that the quartz fraction contains $100 \%$ volcanic monocrystalline quartz with non-undulose extinction, melt inclusions, zoning, or homogeneous or patchy CL (Fig. 5A). No grains with microcracks, healed fractures, or polycrystallinity were observed. The detrital volcanic quartz grains in the lake-shore sediments show the exact same SEM-CL and optical features as the quartz grains in the surrounding volcanic bedrock. Thus the quartz grains from Lake Taupo provide a robust test of the integrated SEM-CL/optical petrography provenance analysis technique. 


\section{Broken River Formation, Mt. Somers}

In the Mount Somers area (Fig. 2) the local geology is characterized by four stratigraphic units. The basement consists of prehnite-pumpellyite facies, metasedimentary rocks of the Torlesse Supergroup overlain by Cretaceous (92-98 Ma) calc-alkaline volcanic rocks of the Mount Somers Group. The Mount Somers Group consists of domes, flows, tuffs, and ignimbrites, ranging in composition from high-alumina basalt to relatively quartz rich rhyolite (Adams and Oliver 1979; Tappenden 2003). The Torlesse Supergroup and the Mount Somers Group volcanic rocks are both stratigraphically succeeded by Upper Cretaceous to Tertiary transgressive sedimentary deposits (van der Lingen 1988). The basal sedimentary units of the Early Eocene to Oligocene Broken River Formation include terrestrial coal and clay deposits that grade upward into shallow marine quartz arenite (van der Lingen 1988).

In order to be able to recognize the volcanic sources, we analyzed rhyolite and ignimbrite samples of the Mount Somers volcanic rocks with the combined SEM-CL/optical microscopy technique (Fig. 1C, D). We found that quartz grains of the Mount Somers volcanic rocks are usually large, pristine crystals with non-undulose extinction and large open fractures, showing either homogeneous CL or zoning (Fig. 1C, D). None of the local volcanic rocks analyzed in this study showed quartz grains with microcracks and/or healed fractures. The large open fractures, which were formed during rapid cooling of the quartz grains, cause disintegration of the grains as soon as they weather out of their source rock, leading to a much smaller grain size than the original crystals.

A suite of samples of the Broken River Formation was collected from a silica-sand quarry northwest of the village of Mount Somers. The local Cretaceous volcanic rocks have been identified in the past as the primary source for the quartz, with a minor metamorphic input from the Otago Schist as indicated by the presence of schist pebbles (van der Lingen 1988). Integrated SEM-CL/optical microscopy analysis shows that on average $\sim 45 \%$ of the quartz grains are of volcanic origin, $\sim 23 \%$ are derived from metamorphic source rocks, and $~ 33 \%$ show characteristics of plutonic quartz (Fig. 5A). Well rounded recrystallized, high-grade metamorphic quartz occurs mainly in the coarse size fraction. 


\section{Broken River Formation, Glens of Tekoa}

We also sampled the Broken River Formation quartz arenite at an outcrop along Coal Creek near Glens of Tekoa, New Zealand (Fig. 2). The basement in this area again consists of metasedimentary rocks of the Torlesse Supergroup intruded by Cretaceous syenites and trachytes (Tappenden 2003). The basement is unconformably overlain by a basal boulder conglomerate dominated by clasts from the local underlying Cretaceous syenite intrusion. The basal conglomerate is succeeded by glauconitic quartz arenite, which is about $20 \mathrm{~m}$ thick at the sample location. Results form traditional point counting indicate that this deposit has $~ 53 \%$ quartz grains, $\sim 1 \%$ feldspar, $12 \%$ glauconite, and a fairly high matrix content of $~ 34 \%$ silt-sized quartz grains and carbonate cement and mud (Table 3).

The local Broken River Formation quartz arenite has a bimodal grain-size distribution of coarse sand to granule sized quartz grains and fine sand, ignoring the matrix. The finer, subrounded to subangular fraction consists of a mixture of polycrystalline and monocrystalline quartz. Using the integrated SEM-CL/optical microscopy technique, monocrystalline grains with non-undulose to undulose extinction, showing microcracks and healed fractures in the finer fraction were identified as plutonic quartz. In fact $~ 44 \%$ of the quartz grains in this sample are of plutonic origin. We identified about $17 \%$ of the grains to have monocrystalline, light CL with non to slightly undulose extinction. As a result, these grains are possibly volcanic in origin. However, because most of these grains were found in the fine to very fine size fraction, this result should not be overinterpreted.

The coarse fraction is well rounded and consists entirely of polycrystalline quartz that appears black in SEM-CL images, identifying it as high-grade metamorphic and/or recrystallized quartz. This fraction makes up $\sim 40 \%$ of the total quartz-grain counts, an unexpectedly high percentage but similar to that identified for the Mt. Somers locality.

\section{DISCUSSION}

The Lake Taupo sample is regarded here as a simple test of our technique in a fully volcanic environment. Local provenance of volcanic quartz was expected, because of the geological setting and the composition of the other framework grains. Therefore, our result of $100 \%$ volcanic quartz is no surprise. However, there was a possibility of minor amounts of plutonic quartz in the sediment being 
derived from granodioritic xenoliths, which are found in andesites, dacites and ignimbrites of the TVZ (Burt et al. 1998; Cole et al. 2001). Nevertheless, such plutonic quartz was not detected, and therefore the Lake Taupo sediments confirm that quartz with microcracks and/or healed fractures or recrystallized quartz do not occur in volcanically derived sediment.

The quartz arenites of the Broken River Formation near Mount Somers show a more complex pattern with a mixture of different quartz types. So far the Mount Somers volcanic rocks have always been regarded as the primary quartz source for the Broken River Formation quartz arenites in the Mount Somers area with minor input from the Otago Schist (van der Lingen 1988). Throughout the section we found that almost half the quartz grains were derived from the local Mount Somers volcanic rocks. However, other grains show characteristics of metamorphic or plutonic affinity. The local Torlesse Supergroup is known for its abundance of vein quartz (Oliver et al. 1982), and given the widespread prehnite-pumpellyite facies metamorphic overprint $\left(\sim 300-400^{\circ} \mathrm{C}\right)$ we believe that the metamorphic and vein quartz from this source is similar to such quartz types studied elsewhere on the South Island of New Zealand (data archive). Therefore, we think that most metamorphic quartz in our fine size fraction came from outcrops of the Torlesse Supergroup. At least some sediment input from more distal metamorphic sources such as the Otago Schist is indicated by the presence of metamorphic conglomerate clasts in the upper part of the stratigraphic section (van der Lingen 1988). This corresponds to an increase in coarse, well rounded sand grains of metamorphic quartz in the upper half of the section. The degree of rounding and the high metamorphic grade support an interpretation of transport by alongshore currents from the Otago Schist, as suggested earlier by van der Lingen (1988).

The most surprising result of the Mount Somers quartz arenite study is that about $1 / 3$ of the grains throughout the section are of plutonic origin. Because there are no known local sources of plutonic quartz in the Mount Somers area, we have to conclude that these quartz grains must have been imported from distant plutonic sources. We think the most likely plutonic sources include the Devonian and Cretaceous granitoids of the Karamea batholith (Muir et al. 1996), the Cretaceous Hohonu batholith (Waight et al. 1997), or the Carboniferous and Cretaceous granitic rocks of Fiordland (Muir et al. 1998), all on the South Island of New Zealand (Fig. 2). At least some of these plutonic sources were exposed at the time of deposition of the Mount Somers quartz arenites. These 
sources were located to the WSW of the Mount Somers area during the Eocene, before onset of major displacement of the Karamea and Hohonu batholith along the Alpine Fault since the Miocene. Despite the proposed long-distance transport (at least $300-400 \mathrm{~km}$ ) of plutonic quartz, most of these grains do not show a higher degree of textural maturity, and most are still fairly angular to subrounded. This indicates a different transport history, most likely in a fluvial setting, in comparison to the alongshore transport of the well rounded metamorphic grains.

An interesting result for the Glens of Tekoa Broken River Formation sample is the striking relation between certain quartz types and grain rounding and/or grain size, with plutonic quartz grains dominating the medium to fine fraction and metamorphic quartz dominating the very coarse to coarse fraction. We think the plutonic and metamorphic quartz were derived from distant sources, which is also the most likely explanation as presented for the Mt. Somers locality. However, an alternate interpretation is that all of the quartz grains are locally derived from the local syenite intrusion, the associated volcanic rocks, and the metamorphosed Torlesse Supergroup, which also contains abundant quartz veins close to the sample location. Exclusively local derivation is possible because coarse plutonic quartz breaks down rapidly under mechanical force, because of its preexisting microcracks (Moss 1972a, 1972b). Vein quartz, on the other hand, is much more solid and resistant during transport and reworking (Moss 1972a), particularly if it consists of recrystallized mosaic quartz. However, the different rounding textures of the quartz grains in the Broken River Formation suggest different transport paths, with very well rounded quartz more likely to have been transported by nearshore marine processes and the more angular quartz grains transported by fluvial processes. As a result we think the most likely quartz sources for the Broken River Formation at Glens of Tekoa are from a combination of local plutonic and volcanic sources and a distal metamorphic source such as the Otago Schist, which is widespread over the South Island.

\section{CONCLUSIONS}

We think that the integrated SEM-CL/optical microscopy analysis on single quartz grains combined with conventional point counting is a promising tool to determine quartz provenance. This type of analysis provides large amounts of useful new data by (1) giving us the opportunity to 
differentiate between major quartz types such as plutonic, volcanic, and metamorphic quartz, (2) allowing us to quantify their occurrence statistically by quartz-type point counts, and (3) providing the opportunity to study the relation between quartz type and textural maturity or grain size. Because this technique is particularly well suited for quartz rich sediments, it gives us provenance information on a mineral that has been difficult to analyze in the past. Furthermore, this technique is fairly simple and relatively inexpensive. The critical aspect is to conduct SEM-CL image analysis and optical microscopy on the same quartz grains in each sample.

As with any other technique, this approach has a limited resolution that is reflected by the difficulty in distinguishing between some volcanic quartz, vein quartz, and other metamorphic quartz in the fine sand fraction. Furthermore, when dealing with strongly deformed, metamorphic or partially recrystallized grains, one will find that there are no clear-cut boundaries between these quartz types, but rather a broad transition between end-member types. Nevertheless, we find that the integrated technique works very well for coarse to medium sand sized grains and can be easily combined with other provenance techniques such as point counting, heavy mineral analysis, or additional chemical, isotopic or fluid inclusion analyses of specific quartz types. Because of this compatibility, we think that integrated SEM-CL/optical microscopy analysis on quartz grains has the potential to develop into a standard technique for quartz provenance analysis.

\section{ACKNOWLEDGMENTS}

We are thankful to Neil Andrews from the School of Biological Sciences, University of Canterbury, for his help with using the scanning electron microscope, and to Robert Spiers from the Department of Geological Sciences for thin-section preparation. This research was supported by a postdoctoral research fellowship (Bernet) from the University of Canterbury. Discussion with David Shelley, Steve Weaver, and Anekant Wandres, on quartz deformation features and comments on an earlier version of this manuscript ,are gratefully acknowledged. We also thank Kitty Milliken, Sam Boggs Jr., and an anonymous reviewer for critical yet constructive reviews which helped to improve the manuscript significantly. 


\section{REFERENCES}

Adams, C.J.D., and Oliver, P.J., 1979, Potassium-argon dating of Mt Somers Volcanics, South Island, New Zealand: Limitations in dating Mesozoic volcanic rocks: New Zealand Journal of Geology and Geophysics, v. 22, p. 455-463.

Basu, A., Young, S.W, Suttner, L.J., James, W.C., and Mack, G.H., 1975, Re-evaluation of the use of undulatory extinction and polycrystallinity in detrital quartz for provenance interpretation: Journal of Sedimentary Petrology, v. 45, p. 873-882.

Boggs, S., Jr., Krinsley, D.H., Goles, G., Seyedolali, A., and Dypvik, H., 2001, Identification of shocked quartz by scanning cathodoluminescence imaging: Meteoritics and Planetary Science, v. 36, p. $783-791$.

Boggs, S., Jr., Kwon, Y.I., Goles, G., Rusk, B.G., Krinsely, D., and Seyedolali, A., 2002, Is quartz cathodoluminescence color a reliable provenance tool? A quantitative examination: Journal of Sedimentary Research, v. 72, p. 408-415.

Burt, R.M., Brown, S.J.A., Cole, J.W., Shelley, D., and Waight, T.E., 1998, Glass-bearing plutonic fragments from ignimbrites of the Okataina caldera complex, Taupo Volcanic Zone, New Zealand: Remnants of a partially molten intrusion associated with preceding eruptions: Journal of Volcanology and Geothermal Research, v. 84, p. 209-237.

Cole, J.W., Brown, S.J.A., Burt, R.M., Beresford, S.W., and Wilson, C.J.N., 1998, Lithic types of ignimbrites as a guide to the evolution of a caldera complex, Taupo volcanic centre, New Zealand: Journal of Volcanology and Geothermal Research, v. 80, p. 217-237.

Cole, J.W., Gamble, J.A., Burt, R.M., Carroll, L.D., and Shelley, D., 2001, Mixing and mingling of andesite-dacite magmas: evidence from co-magmatic plutonic enclaves, Taupo Volcanic Zone, New Zealand: Lithos, v. 59, p. 25-46.

Dickinson, W.W., and Milliken, K.L., 1995, The diagenetic role of brittle deformation in compaction and pressure solution, Etjo Sandstone, Namibia: Journal of Geology, v. 103, p.339-347.

D’Lemos, R.S., Kearsley, A.T., Pembroke, J.W., Watt, G.R., and Wright, P., 1997, Complex quartz growth histories in granite revealed by scanning cathodoluminescence techniques: Geological Magazine, v. 134, p. 549-552. 
Hogg, A.J.C., Seller, E., and Jourdan, A.J., 1992, Cathodoluminescence of quartz cements in Brent Group sandstones, Alwyn South, UK North Sea, in Morton, A.C., Haszeldine, R.S., Giles, M.R., and Brown, S., eds., Geology of the Brent Group: Geological Society of London Special Publication, 61, p. 421-440.

Houseknecht, D.W., 1991, Use of Cathodoluminescence petrography for understanding compaction, quartz cementation, and porosity in sandstones, in Barker, C.E., and Kopp, O.C., eds., Luminescence Microscopy: Quantitative and Qualitative Aspects: SEPM Short Course No 25. , p. 59-66.

Kanaori, Y., 1986, A SEM cathodoluminescence study of quartz in mildly deformed granite from the region of the Atotsugawa fault, central Japan: Tectonophysics, v. 131, p. 133-146.

Kwon, Y.I., and Boggs, S., 2002, Provenance interpretation of Tertiary sandstones from the Cheju Basin (NE East China Sea): a comparison of conventional petrographic and scanning cathodoluminescence techniques: Sedimentary Geology, v. 152, p. 29-43.

McBride, E.F., 1963, A classification of common sandstones: Journal of Sedimentary Petrology, v. 33, p. 664-669.

Milliken, K.L., 1994, Cathodoluminescent textures and the origin of quartz silt in Oligocene mudrocks, South Texas: Journal of Sedimentary Research, v. A64, p. 567-571.

Milliken, K.L., and Laubach, S.E., 2000, Brittle deformation of sandstone diagenesis as revealed by scanning cathodoluminescence imaging with application to characterization of fractured reservoirs, in Pagel, M., Barbin, V., Blanc, P., and Ohnenstetter, D., eds., Cathodoluminescence in Geosciences: Berlin, Springer-Verlag, p. 225-244.

Moss, A.J., 1972a, Technique for assessment of particle breakage in natural and artificial environments: Journal of Sedimentary Petrology, v. 42, p. 725-728.

Moss, A.J., 1972b, Initial fluviatile fragmentation of granitic quartz: Journal of Sedimentary Petrology, v. 42, p. 905-916.

Moss, A.J., and Green, P., 1975, Sand and silt grains: Predetermination of their formation and properties by microfractures in quartz: Geological Society of Australia, Journal, v. 22, p. 485-495. 
Muir, R.J., Weaver, S.D., Bradshaw, J.D., Eby, G.N., Evans, J.A., and Ireland, T.R., 1996, Geochemistry of the Karamea Batholith, New Zealand and comparisons with the Lachlan Fold Belt granites of SE Australia: Lithos, v. 39, p. 1-20.

Muir, R.J., Ireland, T.R., Weaver. S.D., Bradshaw, J.D., Evans, J.A., Eby, G.N., and Shelley, D., 1998, Geochronology and geochemistry of Mesozoic magmatic arc systems, Fiordland, New Zealand: Geological Society of London, Journal, v. 155, p. 1037-1053.

Oliver, P.J., Campbell, J.D., and Speden, I.G., 1982, The stratigraphy of the Torlesse rocks of the Mt Somers area (S81) mid-Canterbury. Journal of the Royal Society of New Zealand, v. 12, p. 243-271.

Onasch, C.M., and Vennemann, T.W., 1995, Disequilibrium partioning of oxygen isotopes associated with sector zoning in quartz: Geology, v. 23, p. 1103-1106.

Passchier, C.W., and Trouw, R.A.J., 1996, Microtectonics: Berlin, Springer-Verlag, 289 p.

Perny, B., Eberhardt, P., Ramseyer, K., Mullis, J., and Pankrath, R. 1992, Microdistribution of Al, Li, and $\mathrm{Na}$ in alpha quartz: Possible causes and correlation with short-lived cathodoluminescence: American Mineralogist, v. 77, p. 534-544.

Ramseyer, K., and Mullis, J., 2000, Geologic application of cathodoluminescence of silicates, in Pagel, M., Barbin, V., Blanc, P., and Ohnenstetter, D., eds., Cathodoluminescence in Geosciences: Berlin, Springer-Verlag, p. 177-191.

Rusk, B., and Reed, M., 2002, Scanning electron microscope-cathodoluminescence analysis of quartz reveals complex growth histories in veins from the Butte porphyry copper deposit, Montana: Geology, v. 30, p. 727-730.

Sanderson, I.D., 1984, Recognition and significance of inherited quartz overgrowths in quartz arenites: Journal of Sedimentary Petrology, v. 54, p. 473-486.

Seyedolali, A., Krinsley, D.H., Boggs S., Jr., O’Hara, P.F., Dypvik, H., and Goles, G.G., 1997, Provenance interpretation of quartz by scanning electron microscope-cathodoluminescence fabric analysis: Geology, v.25, p. 787-790.

Smith, G., and Landis, C., 1995, Intra-arc basins, in Busby, C.J., and Ingersoll, R.V., eds., Tectonics of Sedimentary Basins: Blackwell Science, Cambridge, Massachusetts, p. 263-298. 
Sprunt, E.S., Dengler, L.A., and Sloan, D., 1978, Effects of metamorphism on quartz cathodoluminescence: Geology, v. 6, p. 305-308.

Sprunt, E.S., and Nur, A., 1979, Microcracking and healing in granites: New evidence from cathodoluminescence: Science, v. 205, p. 495-497.

Stevens-Kalceff, M.A., Phillips, M.R., Moon, A.R., and Kalceff, W., 2000, Cathodoluminescence microcharacterisation of silicon dioxide polymorphs, in Pagel, M., Barbin, V., Blanc, P., and Ohnenstetter, D., eds., Cathodoluminescence in Geosciences: Berlin, Springer-Verlag, p. 193-224.

Tappenden, V., 2003, Magmatic response to the evolving New Zealand margin of Gondwana during the Late Cretaceous: Unpublished PhD thesis, University of Canterbury, Christchurch, New Zealand, 235p.

Tortosa, A., Palomares, M., and Arribas, J., 1991, Quartz grain types in Holocene deposits from the Spanish Central System: some problems in provenance analysis, in Morton, A.C., Todd, S.P., and Haughton, P.D.W., eds., Developments in Sedimentary Provenance Studies: Geological Society of London, Special Publication, 157, p. 47-54.

van der Lingen, G.J., 1988, Lower Tertiary transgressive sediments of the Broken River Formation, Mt Somers area, Canterbury, New Zealand: New Zealand Journal of Geology and Geophysics, v. 31, p. 287-304.

Waight, T.E., Weaver, S.D., Ireland, T.R., Maas, R., Muir, R.J., and Shelley, D., 1997, Field characteristics, petrography, and geochronology of the Hohonu Batholith and the adjacent Granite Hill complex, North Westland, New Zealand: New Zealand Journal of Geology and Geophysics, v. 40, p. $1-17$.

Walderhaug, O., and Rykkje, J., 2000, Some examples of the effect of crystallographic orientation on cathodoluminescence colors of quartz: Journal of Sedimentary Research, v. 70, p. 545-548.

Watt, G.R., Wright, P., Galloway, S., and McLean, C., 1997, Cathodoluminescence and trace element zoning in quartz phenocrysts and xenocrysts: Geochimica et Cosmochimica Acta, v. 61, p. 4337-4348.

Young, S.W., 1976, Petrographic textures of detrital polycrystalline quartz as an aid in interpreting crystalline source rocks: Journal of Sedimentary Petrology, v. 46, p. 595-603. 


\section{FIGURE CAPTIONS}

Fig. 1 A-B) SEM-CL images of plutonic quart from the Hohonu Batholith, showing typical randomly oriented microcracks and healed cracks. Note also a set of preferably oriented microfractures caused by brittle deformation. C-D) SEM-CL images of volcanic quartz of the Mount Somers rhyolite and ignimbrite. Some grains show homogeneous CL while other grains display zoning. Note typical features such as large open cracks, embayments, and melt inclusions. E) Example of a remnant of plutonic quartz in recrystallized granitic gneiss. The remnant shows microcracks from original cooling, and a set of preferred oriented microfractures from brittle deformation. The recrystallized edges of this quartz crystal are black in the SEM-CL image. F) Vein quartz from the Alpine Schist, collected at Haast Pass, South Island, New Zealand, showing well developed narrowly spaced oscillatory zoning with sharp corners.

Fig. 2 Shown here are sediment sample locations of Lake Taupo on the North Island, and Mount Somers and Glens of Tekoa on the South Island of New Zealand. Also shown are the locations of the study areas in the Cretaceous Deutgam granodiorite (Hohonu Batholith) and the Carboniferous Cape Foulwind and Siberia Bay granitic gneiss in the Western Province, South Island, New Zealand (also see data archive).

Fig. 3 A) SEM-CL of mainly metamorphic and plutonic quartz of the Glens of Tekoa (Island Hills) sample. Plutonic quartz is recognized by light gray CL and microcracks. Large rounded clasts with dark CL are recrsytallized clasts. B) Same location on thin section as in part A but showing crosspolarized optical microscopy image. For integrated analysis and quartz-type point count only quartz grains are selected and labeled and all other grains (feldspar, lithics, glauconite etc.) are ignored.

Fig. 4 Flow chart showing steps to identify quartz type on the basis of a combination of CL and petrographic characteristics and features.

Fig. 5 A) Provenance discrimination diagram of Lake Taupo, Mount Somers, and Glens of Tekoa samples using the three main quartz types of volcanic, plutonic, and metamorphic quartz, based on SEM-CL/optical analysis. The dashed lines indicate the 50 percent lines of each of the three main quartz types. Metamorphic quartz includes all low-grade to high-grade metamorphic, recrystallized, and vein quartz. B) Standard QFL diagram after Mc Bride (1963), on the basis of normalized pointcounting results using traditional counting techniques. All analyzed samples of the Broken River Formation plot in the quartz arenite field (> 95\% quartz grains). 
Table 1: Description of SEM-CL characteristics and features

Table 2. Quartz types identified by their combined SEM-CL and optical characteristics and features.

Table 3: Point counting and integrated SEM-CL/optical microscopy results of Lake Taupo Broken River formation samples 
Table 1: Description of SEM-CL characteristics and features

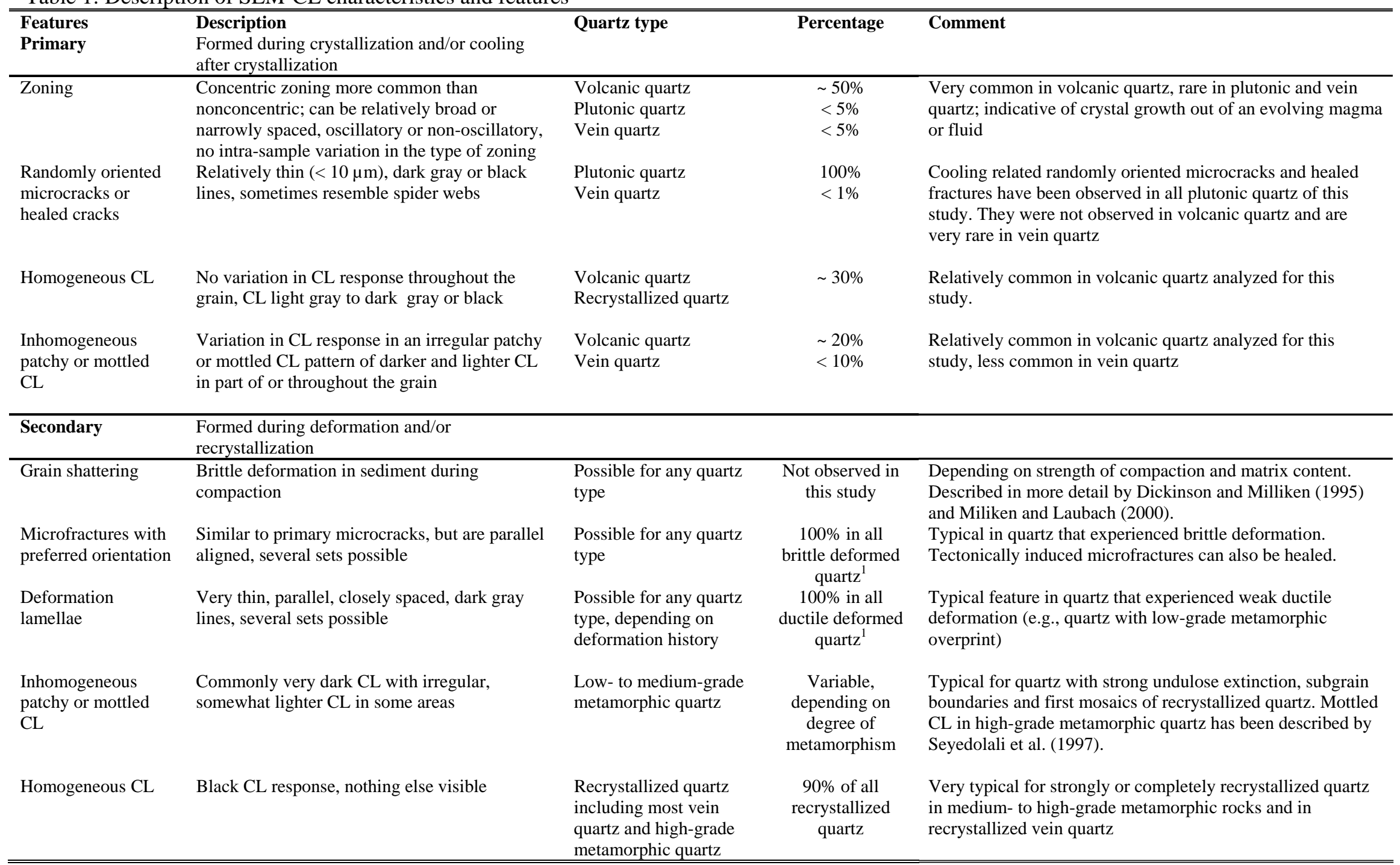

Note: Percentage of primary features is based on counts of samples from this study may vary in samples from other locations (see Seyedolali et al. (1997)

for comparison).

${ }^{1}$ Percentage of secondary features depends on deformation history of source rocks or after deposition and can be highly variable from sample to sample. 
Table 2 Quartz types identified by their combined SEM-CL and optical characteristics and features.

\begin{tabular}{|c|c|c|c|}
\hline Quartz type & SEM-CL features & Optical features & Comments \\
\hline Plutonic quartz & $\begin{array}{l}\text { - light gray CL } \\
\text { - microcracks and healed } \\
\text { cracks (randomly } \\
\text { oriented) } \\
\text { - rare zoning }\end{array}$ & $\begin{array}{l}\text { - monocrystalline or } \\
-<3 \text { polycrystalline } \\
\text { - non-undulose to weak } \\
\text { undulose extinction }\end{array}$ & $\begin{array}{l}\text { May contain fluid-inclusion trails and } \\
\text { mineral inclusions (e.g., apatite or } \\
\text { zircon) }\end{array}$ \\
\hline Volcanic quartz & $\begin{array}{l}\text { - light gray to black CL } \\
\text { - either homogeneous or } \\
\text { patchy CL } \\
\text { - common zoning } \\
\text { - large open cracks }\end{array}$ & $\begin{array}{l}\text { - monocrystalline } \\
\text { - non-undulose extinction } \\
\text { - large open cracks }\end{array}$ & $\begin{array}{l}\text { Inclusions and open cracks can be } \\
\text { seen with both techniques. Cracks } \\
\text { formed during rapid cooling. }\end{array}$ \\
\hline $\begin{array}{l}\text { Brittle deformed } \\
\text { quartz (under very } \\
\text { low-grade } \\
\text { metamorphic } \\
\text { conditions) }\end{array}$ & $\begin{array}{l}\text { - microfractures or healed } \\
\text { fractures with preferred } \\
\text { orientation }\end{array}$ & $\begin{array}{l}\text { - mono- or } \\
\text { polycrystalline } \\
\text { - weakly undulose } \\
\text { extinction }\end{array}$ & $\begin{array}{l}\text { Tectonically induced microfractures } \\
\text { are possible in any quartz type that } \\
\text { experiences brittle deformation. } \\
\text { Several generations of oriented } \\
\text { microfractures or healed fractures are } \\
\text { possible in the same grain }\end{array}$ \\
\hline $\begin{array}{l}\text { Ductile deformed } \\
\text { quartz (under low } \\
\text {-medium grade } \\
\text { metamorphic } \\
\text { conditions) }\end{array}$ & $\begin{array}{l}\text { - deformation lamellae } \\
\text { - complex shear }\end{array}$ & $\begin{array}{l}\text { - weakly to strong } \\
\text { undulose extinction } \\
\text {-deformation lamellae }\end{array}$ & $\begin{array}{l}\text { Tectonically induced deformation } \\
\text { lamellae are possible in any quartz } \\
\text { type that experiences ductile } \\
\text { deformation. } \\
\text { Complex shear patterns were not } \\
\text { observed in this study see Seyedolali } \\
\text { et al. (1997) }\end{array}$ \\
\hline $\begin{array}{l}\text { Low-grade to } \\
\text { medium-grade } \\
\text { metamorphic } \\
\text { quartz }\end{array}$ & $\begin{array}{l}\text { - light gray to black CL } \\
\text { - patchy or mottled CL }\end{array}$ & $\begin{array}{l}\text { - weakly to strong } \\
\text { undulose extinction }\end{array}$ & $\begin{array}{l}\text { Quartz grains of volcanic, plutonic, } \\
\text { or other origin that experienced low- } \\
\text { to medium-grade metamorphic } \\
\text { overprint }\end{array}$ \\
\hline $\begin{array}{l}\text { High-grade } \\
\text { metamorphic } \\
\text { quartz - } \\
\text { recrystallized } \\
\text { quartz }\end{array}$ & - black CL & $\begin{array}{l}\text { - polycrystalline (quartz } \\
\text { mosaics with non- } \\
\text { undulose to weakly } \\
\text { undulose extinction) }\end{array}$ & $\begin{array}{l}\text { Also see Seyedolali et al. (1997) for } \\
\text { more information on CL of high- } \\
\text { grade metamorphic quartz. } \\
\text { Recrystallized quartz is easy to } \\
\text { identify with the optical microscope }\end{array}$ \\
\hline Vein quartz & $\begin{array}{l}\text { - light gray to black CL } \\
\text { - homogeneous CL } \\
\text { - patchy CL } \\
\text { - zoning } \\
\text { - very rare microcracks }\end{array}$ & $\begin{array}{l}\text { - mono- or polycrystalline } \\
\text { - weakly to strongly } \\
\text { undulose extinction }\end{array}$ & $\begin{array}{l}\text { Vein quartz commonly very similar } \\
\text { to metamorphic, recrystallized, or } \\
\text { microcrystalline quartz }\end{array}$ \\
\hline Shocked quartz & $\begin{array}{l}\text { - strong fracture pattern } \\
\text { seen as black lines }\end{array}$ & $\begin{array}{l}\text { - fractures and inclusions } \\
\text { - strongly undulose } \\
\text { extinction }\end{array}$ & $\begin{array}{l}\text { Not observed in this study, } \\
\text { information from Seyedolali et al. } \\
\text { (1997) and Boggs et al. (2001) }\end{array}$ \\
\hline $\begin{array}{l}\text { Recycled detrital } \\
\text { quartz with brittle } \\
\text { deformation } \\
\text { during burial and } \\
\text { diagenesis }\end{array}$ & $\begin{array}{l}\text { - grain shattering (against } \\
\text { grain contact = } \\
\text { diagenetic) }\end{array}$ & $\begin{array}{l}\text { - mono- or poly- } \\
\text { crystalline depending on } \\
\text { quartz type } \\
\text { - weakly to strongly } \\
\text { undulose extinction } \\
\text { (depending on inherited } \\
\text { extinction behavior) }\end{array}$ & $\begin{array}{l}\text { With the optical microscope, grains } \\
\text { look as though if they experienced } \\
\text { pressure solution. SEM-CL shows } \\
\text { grain shattering (Dickinson and } \\
\text { Miliken 1995; Miliken and Laubach } \\
\text { 2000) }\end{array}$ \\
\hline $\begin{array}{l}\text { Microcrystalline } \\
\text { quartz }\end{array}$ & - black CL & - microcrystalline & $\begin{array}{l}\text { Better to identify with optical } \\
\text { microscope }\end{array}$ \\
\hline
\end{tabular}

Note: Light gray, dark gray or black CL are only descriptive terms for CL appearance in panchromatic images. 
Table 3: Point counting and integrated SEM-CL/optical microscopy results of Lake Taupo Broken River formation samples

\begin{tabular}{|c|c|c|c|c|c|c|c|c|c|c|c|c|}
\hline \multirow[b]{2}{*}{ Sample } & \multirow[b]{2}{*}{ grain size } & \multirow[b]{2}{*}{ sorting } & \multirow[b]{2}{*}{ roundness } & \multicolumn{6}{|c|}{ Point counting ${ }^{1}$} & \multicolumn{3}{|c|}{ SEM-CL/optical microscopy ${ }^{2}$} \\
\hline & & & & $\begin{array}{l}\text { mono- } \\
\text { crystalline } \\
\text { Qtz }\end{array}$ & $\begin{array}{l}\text { poly- } \\
\text { crystalline } \\
<3 \text { Qtz }\end{array}$ & $\begin{array}{l}\text { poly- } \\
\text { crystalline } \\
\text { > } 3 \text { Qtz }\end{array}$ & Fsp & Lithic & other & $\begin{array}{l}\text { volcanic } \\
\text { Qtz }\end{array}$ & $\begin{array}{l}\text { plutonic } \\
\text { Qtz }\end{array}$ & $\begin{array}{c}\text { metamorphic } \\
\text { Qtz }\end{array}$ \\
\hline $\begin{array}{l}\text { Lake Taupo } \\
\text { shore sand }\end{array}$ & $\begin{array}{l}\text { medium to } \\
\text { fine sand }\end{array}$ & $\begin{array}{l}\text { moderately } \\
\text { sorted }\end{array}$ & angular & $23 \%$ & $0 \%$ & $0 \%$ & $19 \%$ & $47.7 \%$ & $10.3 \%$ & $100 \%$ & $0 \%$ & $0 \%$ \\
\hline $\begin{array}{l}\text { Mount Somers } \\
\text { 03MB118 }\end{array}$ & $\begin{array}{l}\text { coarse to fine } \\
\text { sand }\end{array}$ & $\begin{array}{l}\text { moderately } \\
\text { sorted }\end{array}$ & $\begin{array}{l}\text { angular to } \\
\text { rounded }\end{array}$ & $72.9 \%$ & $3.2 \%$ & $23.5 \%$ & $0 \%$ & $0.4 \%$ & $0 \%$ & $50 \%$ & $31 \%$ & $19 \%$ \\
\hline $\begin{array}{l}\text { Mount Somers } \\
\text { 03MB116 }\end{array}$ & fine sand & $\begin{array}{l}\text { very well } \\
\text { sorted }\end{array}$ & subangular & $85 \%$ & $4 \%$ & $10 \%$ & $0 \%$ & $1 \%$ & $0 \%$ & $47 \%$ & $38 \%$ & $15 \%$ \\
\hline $\begin{array}{l}\text { Mount Somers } \\
03 \text { MB114 }\end{array}$ & $\begin{array}{l}\text { coarse to fine } \\
\text { sand }\end{array}$ & $\begin{array}{l}\text { poorly } \\
\text { sorted }\end{array}$ & $\begin{array}{l}\text { angular to } \\
\text { rounded }\end{array}$ & $52.9 \%$ & $7.6 \%$ & $36.7 \%$ & $0 \%$ & 2.9 & $0 \%$ & $30 \%$ & $29 \%$ & $41 \%$ \\
\hline $\begin{array}{l}\text { Mount Somers } \\
03 \text { MB113 }\end{array}$ & $\begin{array}{l}\text { medium to } \\
\text { fine sand }\end{array}$ & well sorted & subangular & $72.3 \%$ & $6 \%$ & $20.3 \%$ & $0 \%$ & 1.3 & $0 \%$ & $51 \%$ & $25 \%$ & $24 \%$ \\
\hline $\begin{array}{l}\text { Mount Somers } \\
03 \text { MB111 }\end{array}$ & $\begin{array}{l}\text { medium to } \\
\text { fine sand }\end{array}$ & well sorted & subangular & $73.9 \%$ & $5.3 \%$ & $20.8 \%$ & $0 \%$ & $0 \%$ & $0 \%$ & $45 \%$ & $32 \%$ & $23 \%$ \\
\hline $\begin{array}{l}\text { Mount Somers } \\
03 \mathrm{MB} 110\end{array}$ & $\begin{array}{l}\text { medium to } \\
\text { fine sand }\end{array}$ & well sorted & subangular & $76.3 \%$ & $7.3 \%$ & $16.4 \%$ & $0 \%$ & $0 \%$ & $0 \%$ & $45 \%$ & $41 \%$ & $14 \%$ \\
\hline $\begin{array}{l}\text { Glens of } \\
\text { Tekoa }\end{array}$ & $\begin{array}{l}\text { coarse to fine } \\
\text { sand }\end{array}$ & $\begin{array}{l}\text { poorly } \\
\text { sorted }\end{array}$ & $\begin{array}{l}\text { angular to } \\
\text { rounded }\end{array}$ & $29.3 \%$ & $2.2 \%$ & $21 \%$ & $1.3 \%$ & $0 \%$ & $45.6 \%$ & $17 \%$ & $44 \%$ & $39 \%$ \\
\hline
\end{tabular}

Note: ${ }^{1}$ Point-counting results are given in percentage on the basis of 300 or more point counts. "Other” includes mainly shell fragments and unidentifiable clasts for the Lake Taupo sample, and glauconite; silt-size quartz and carbonate mud matrix in the Glens of Tekoa sample. ${ }^{2}$ SEM$\mathrm{CL} /$ optical microscopy results are on the basis of 100 single-quartz-grain analyses and reflect quartz provenance only. The metamorphic-quartz category includes recrystallized and vein quartz. 


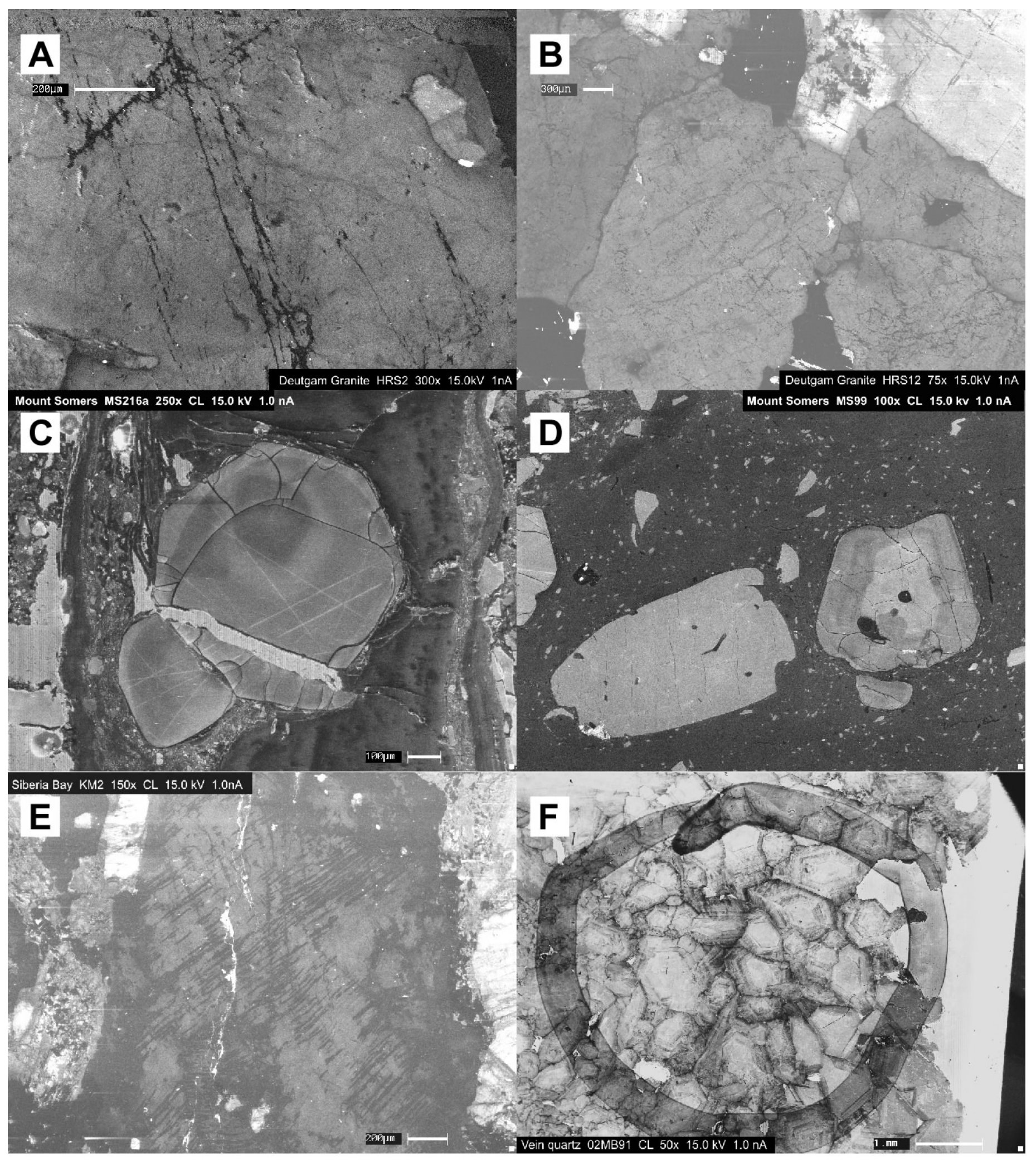

Fig. 1 


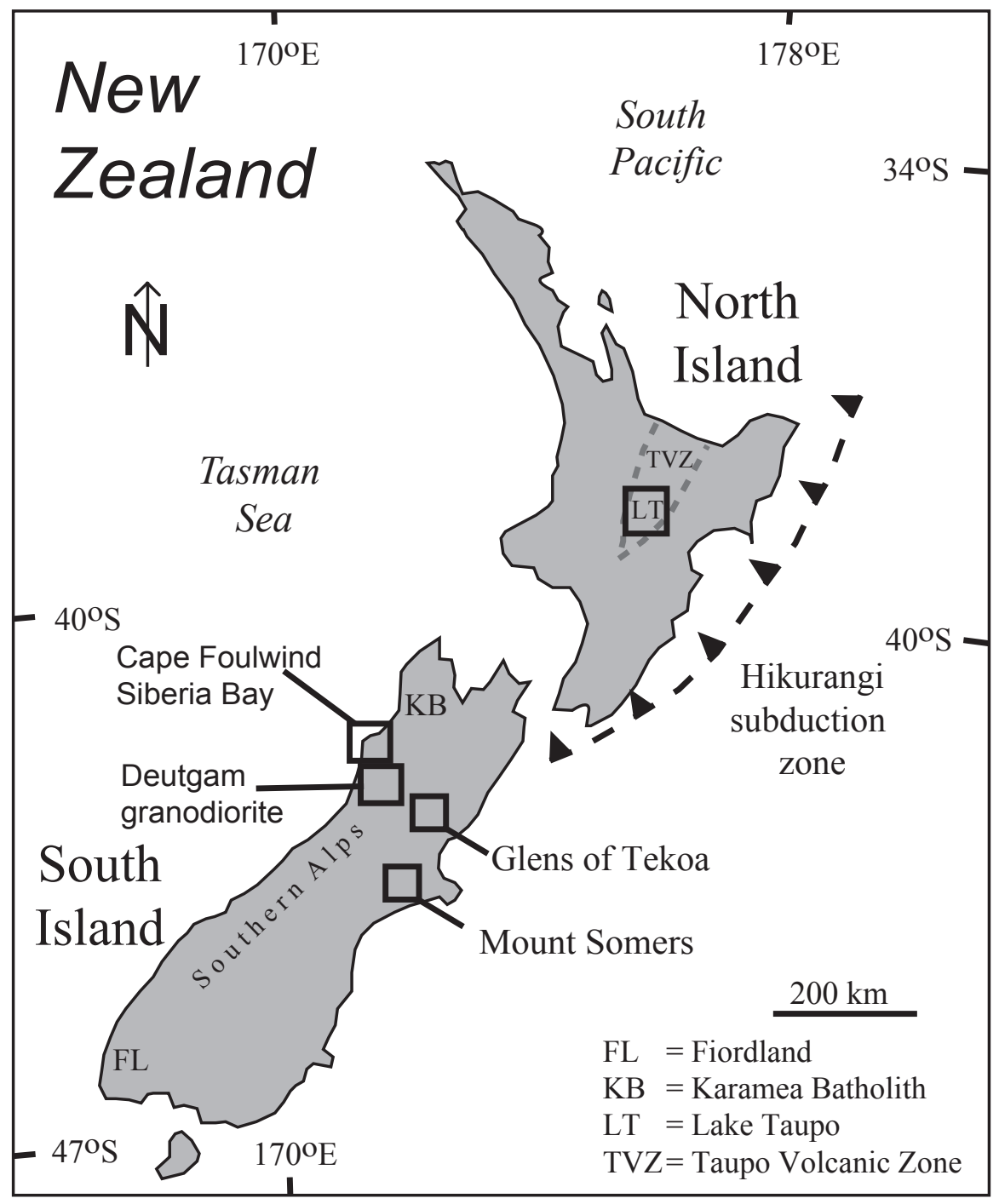




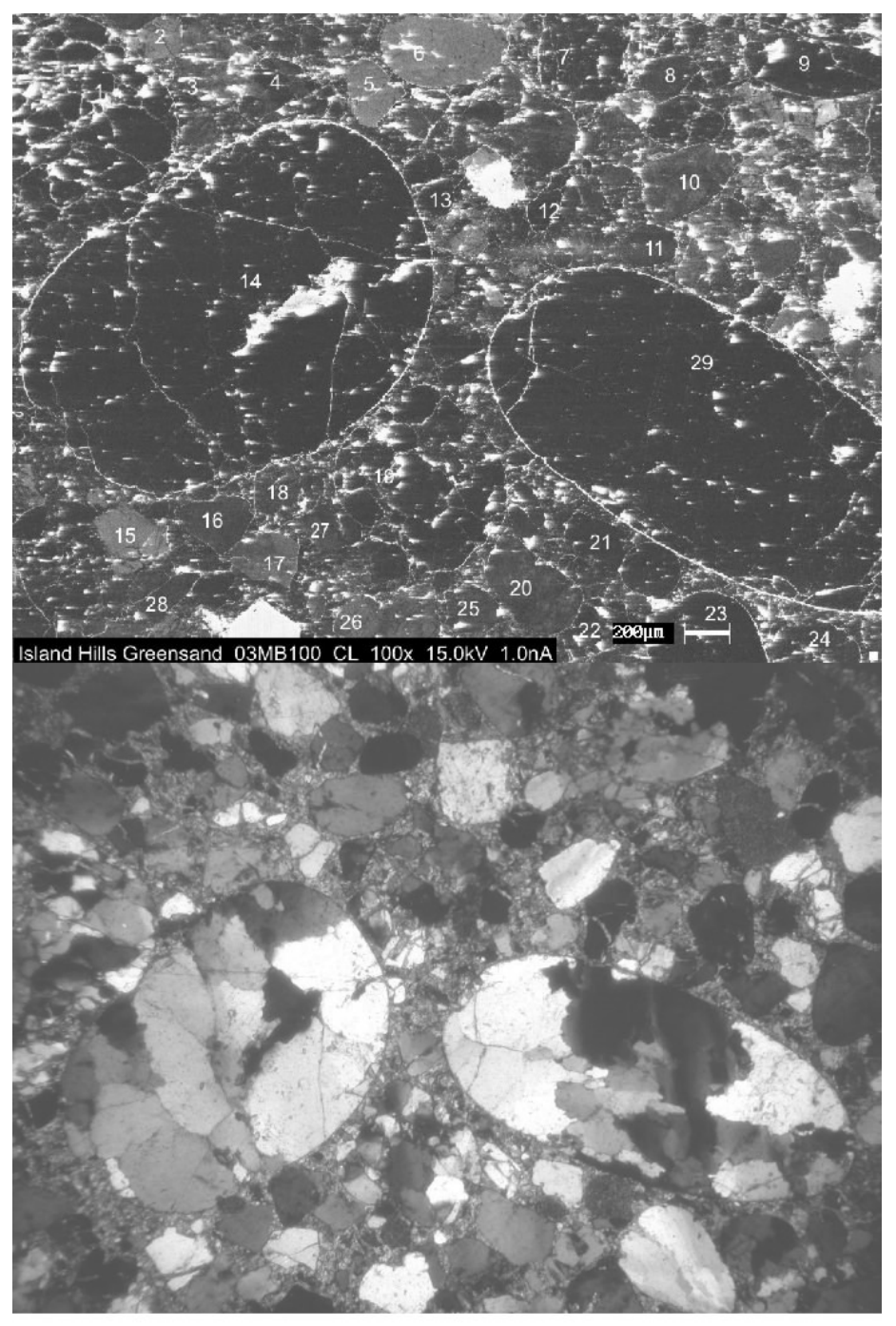

Fig. 3 


\section{Integrated SEM-CL/optical microscopy analysis}

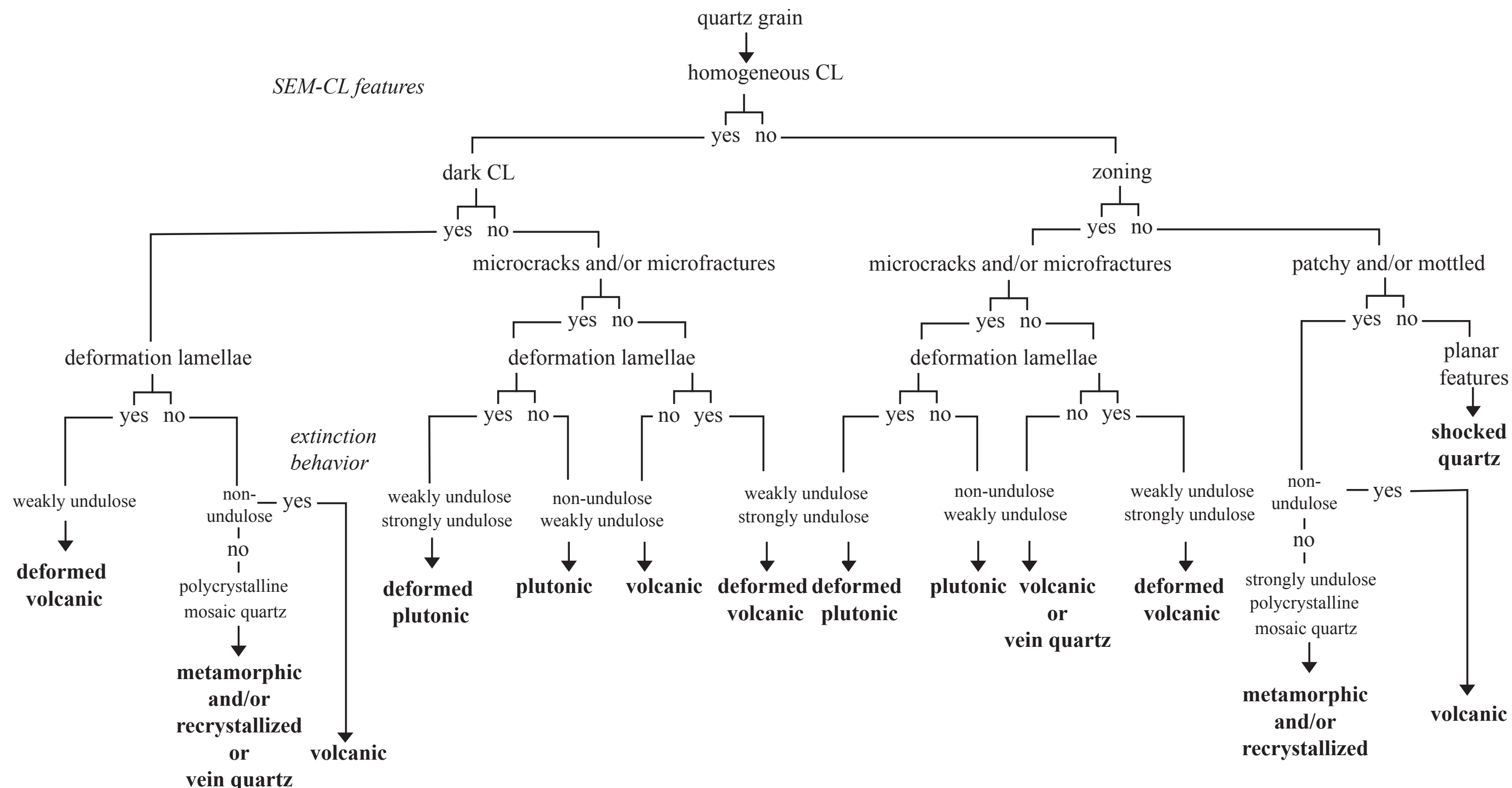




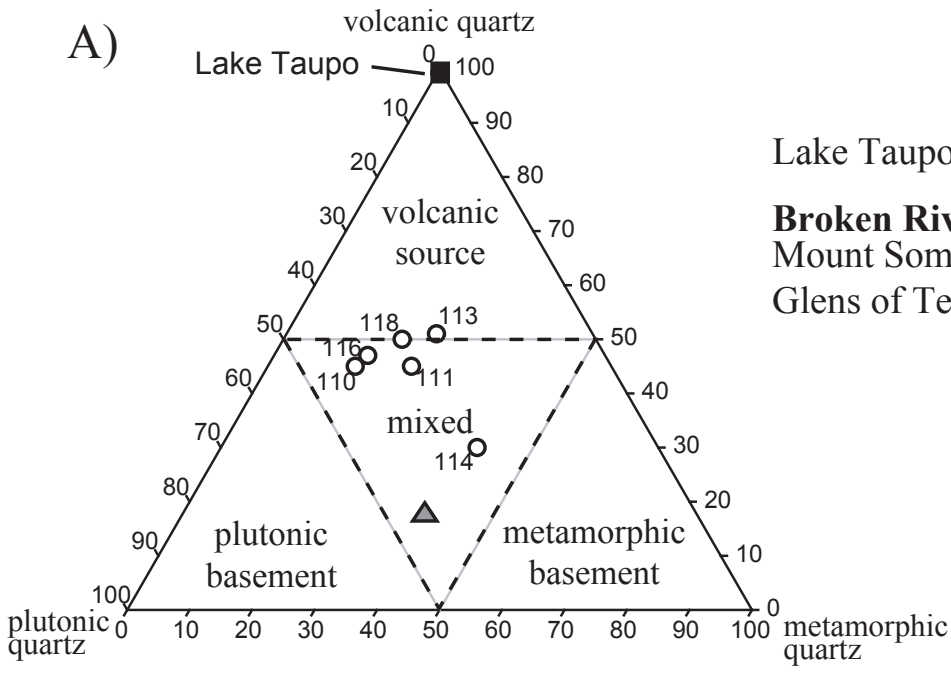

B) Quartz

B)

Lake Taupo

Broken River Fm

Mount Somers O

Glens of Tekoa $\Delta$

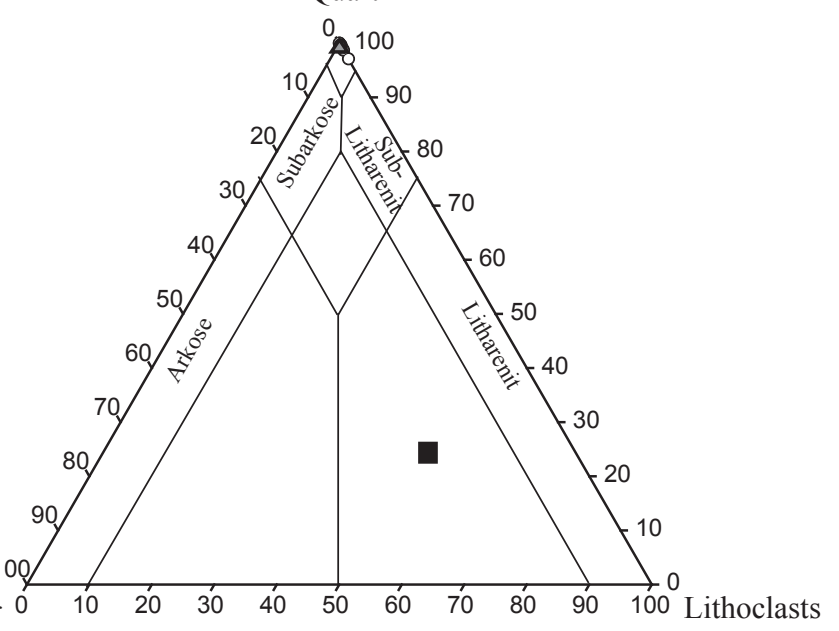

